Proc. Indian Acad. Sci. (Earth Planet. Sci.), Vol. 95, No. 1, March 1986, pp. 131-141.

(C) Printed in India.

\title{
Base metal exploration by gravity surveys in a part of the Cuddapah basin (India)-a case study
}

\author{
G RAMADASS, S M VARAPRASADA RAO and N L MOHAN \\ Centre of Exploration Geophysics, Osmania University, Hyderabad 500007, India
}

MS received 15 March 1985; revised 22 October 1985

\begin{abstract}
A closely spaced gravity survey was conducted in the Chikativaripally area in the Cuddapah basin, Andhra Pradesh, India for base metal exploration. Analysis of the data using two-dimensional prismatic models suggest a doubly plunging folded structure in the area and also its associated mineralization.
\end{abstract}

Keywords. Cuddapah basin; base metal; exploration; gravity; mineralization.

\section{Introduction}

The Cuddapah basin is one of the most prominent areas in Peninsular India which presents a complicated geological setting. This basin poses many problems to geoscientists regarding economic mineral exploration. The basic geological and geophysical surveys were carried out by a number of workers (King 1872; Glennie 1932; Coulson 1933; Narayanaswamy 1959; Reddy et al 1967; Qureshy et al 1968; Balakrishna et al 1970 and Murthy et al 1978). These studies are confined to systematic geological mapping and regional geophysical surveys over this basin.

In the Zangamrajupalle-Varikunta area of the Cuddapah basin lead, zinc mineralization occurs in the shale-dolomitic limestone. Though the mineralized belt extends for over $45 \mathrm{~km}$, reasonable concentration of the ore has been so far observed only at Chikativaripalle-Gollapalle area (Krishnaswamy 1982).

In this context the gravity and SP surveys were carried out for base metal exploration, as these methods have become important for delineation of base metal zones in recent years (Turner and Gibb 1979). In particular, the surveys are aimed at identifying major tectonic features in the Chikativaripalle area, which is a potentially mineralized zone. There are certain remarkable features in this area related to cross-folding and enechelon folding (Narayanaswamy 1971).

This paper presents gravity studies in this area which are compared with SP and geochemical data and the model is confirmed from borehole data. An imaginary 3-D model of this area is presented.

\section{Geological setting}

The area around Chikativaripalle village $\left(14^{\circ} 44^{\prime} 00^{\prime \prime}: 78^{\circ} 53^{\prime} 30^{\prime \prime}\right)$ comprises a part of the eastern Cuddapah basin with rock formations belonging to the Cumbum formations of the Nallamalai group of the Cuddapah super group. The rock types are carbonaceous shales, dolomitic limestones, green shales, and pink shales (figure 1). The 


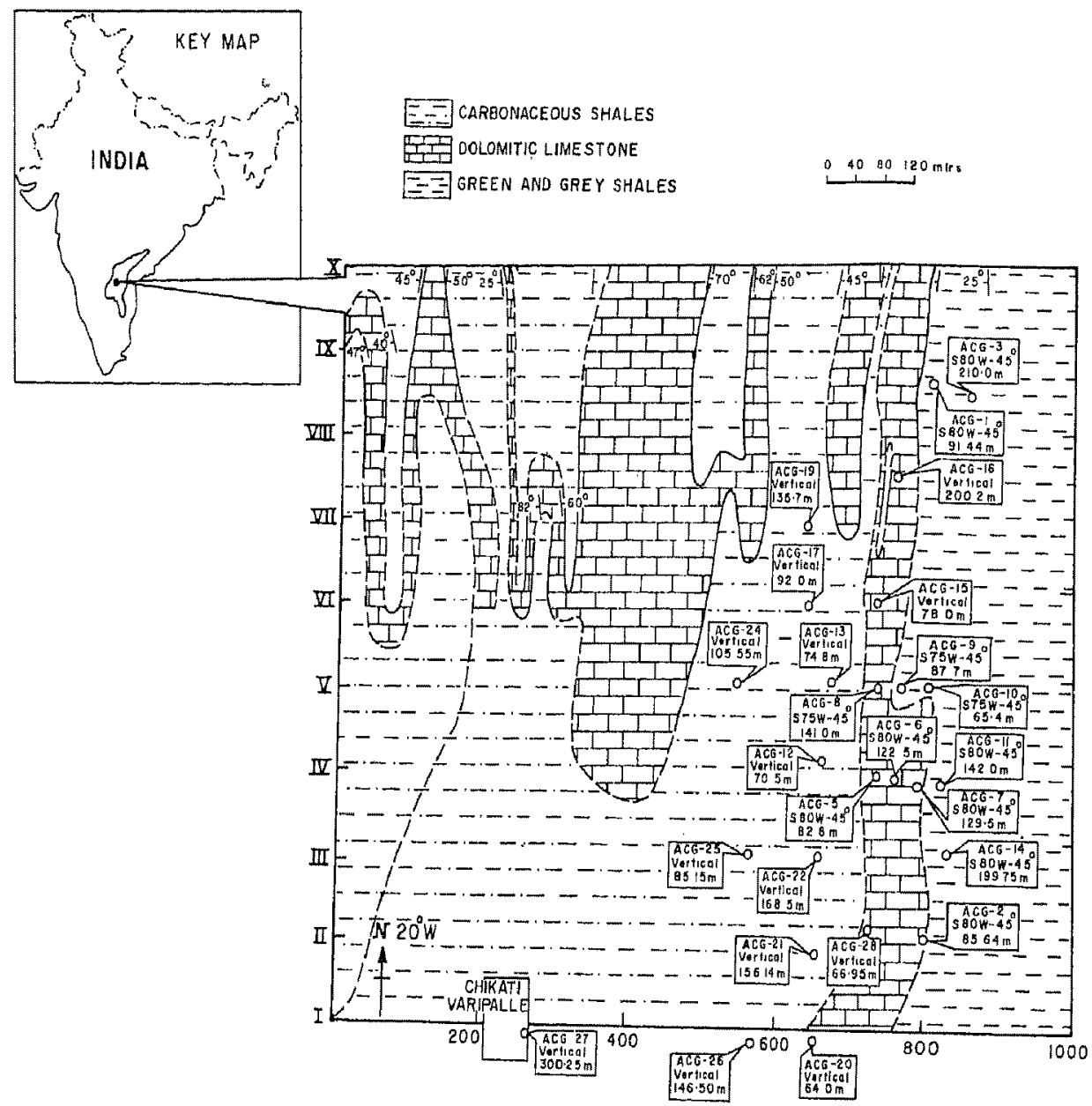

Figure 1. Geological map of the Chikativaripalle area, Cuddapah basin, Andhra Pradesh (Courtesy, GSI)

Chikativaripalle area, where the detailed gravity surveys were carried out, comprises the following stratigraphic sequence (Narayanaswamy 1971 and Krishnaswamy 1982).
Cumbum sub-group
of the Nallamalai
1. Carbonaceous shales $(25-30 \mathrm{~m})$
series of the Cuddapah
2. Massive dolomite $(40-50 \mathrm{~m})$
super group
3. Green shales $(20-60 \mathrm{~m})$
4. Pink shales $(\approx 200 \mathrm{~m})$

The general strike of the formations of the area is $\mathrm{N} 10^{\circ} \mathrm{W}-\mathrm{S} 10^{\circ} \mathrm{E}$ with minor variations. These foldings have resulted in the frequent repetitions of the beds. The regional plunge is $15^{\circ}-20^{\circ}$ towards south. Most of the folds are asymmetrical and some of them are overturned.

In synclinal structures younger carbonaceous shales and dolomites are present, while the anticlinal portions are represented by green and pink shales. The youngest member of the shale group, namely the overlying carbonaceous shale is present in and around 
the Chikativaripalle village. The lead, zinc mineralization is seen as discontinuous stratabound veins or chert zone and copper is found at the base within the dolomite member (Krishnaswamy 1982). The sulphides in this area are found to be syngentic in origin and have clear lithostratigraphic control with subsequent enrichment by remobilization.

\section{Data acquisition and analysis}

In Chikativaripalle area the detailed gravity and SP surveys were carried out over an area of $1 \mathrm{~km}^{2}$. Ten traverses were laid out along $\mathrm{N} 70^{\circ} \mathrm{E}$ at 100 -metre intervals and observations were made at every $20 \mathrm{~m}$. All ten traverses of gravity observations are shown in figures $2,3,4$ and 5 , and the values are tied to a single station situated on

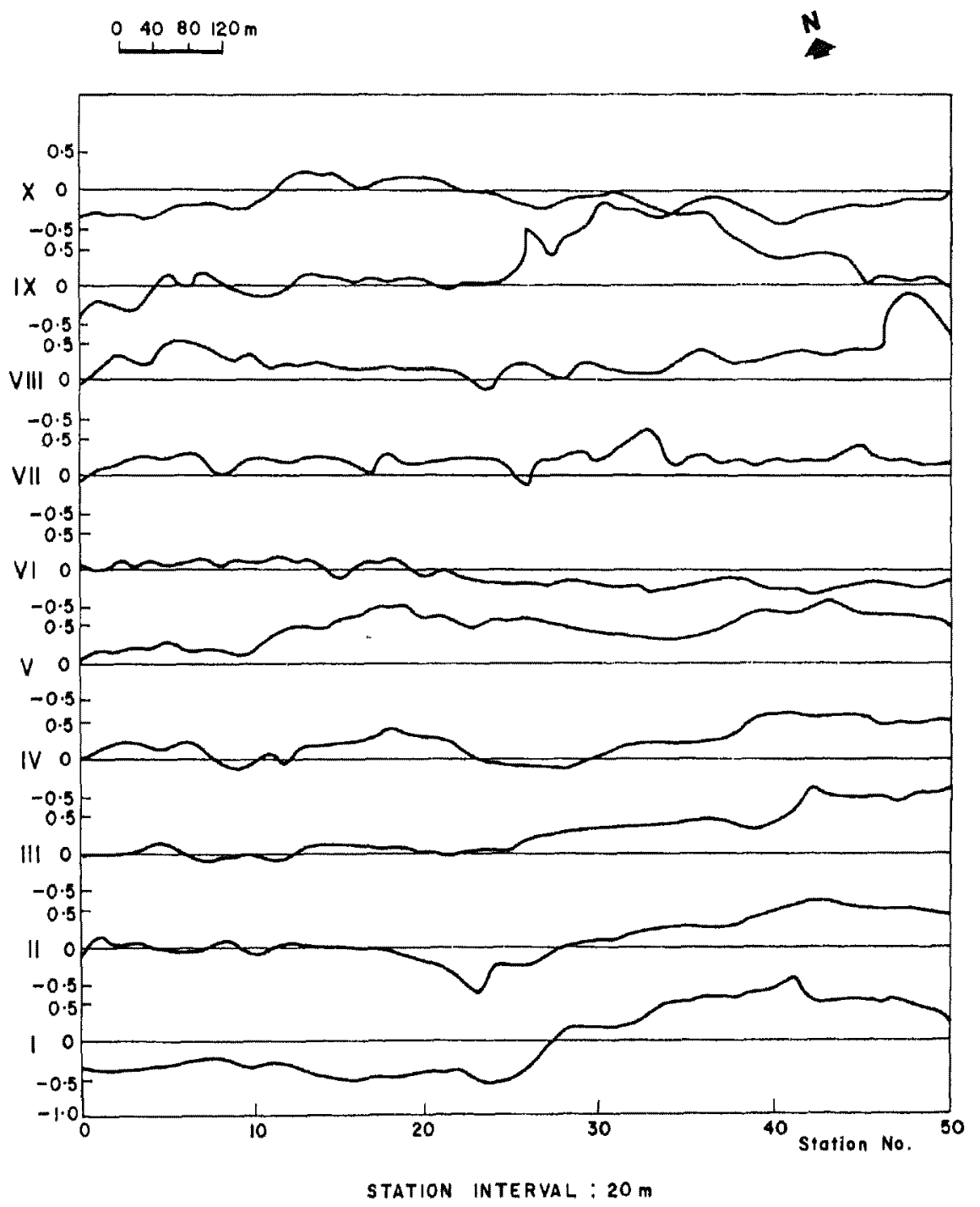

Figure 2. Detailed observed gravity traverses in Chikativaripalle-Gollapalle area. 


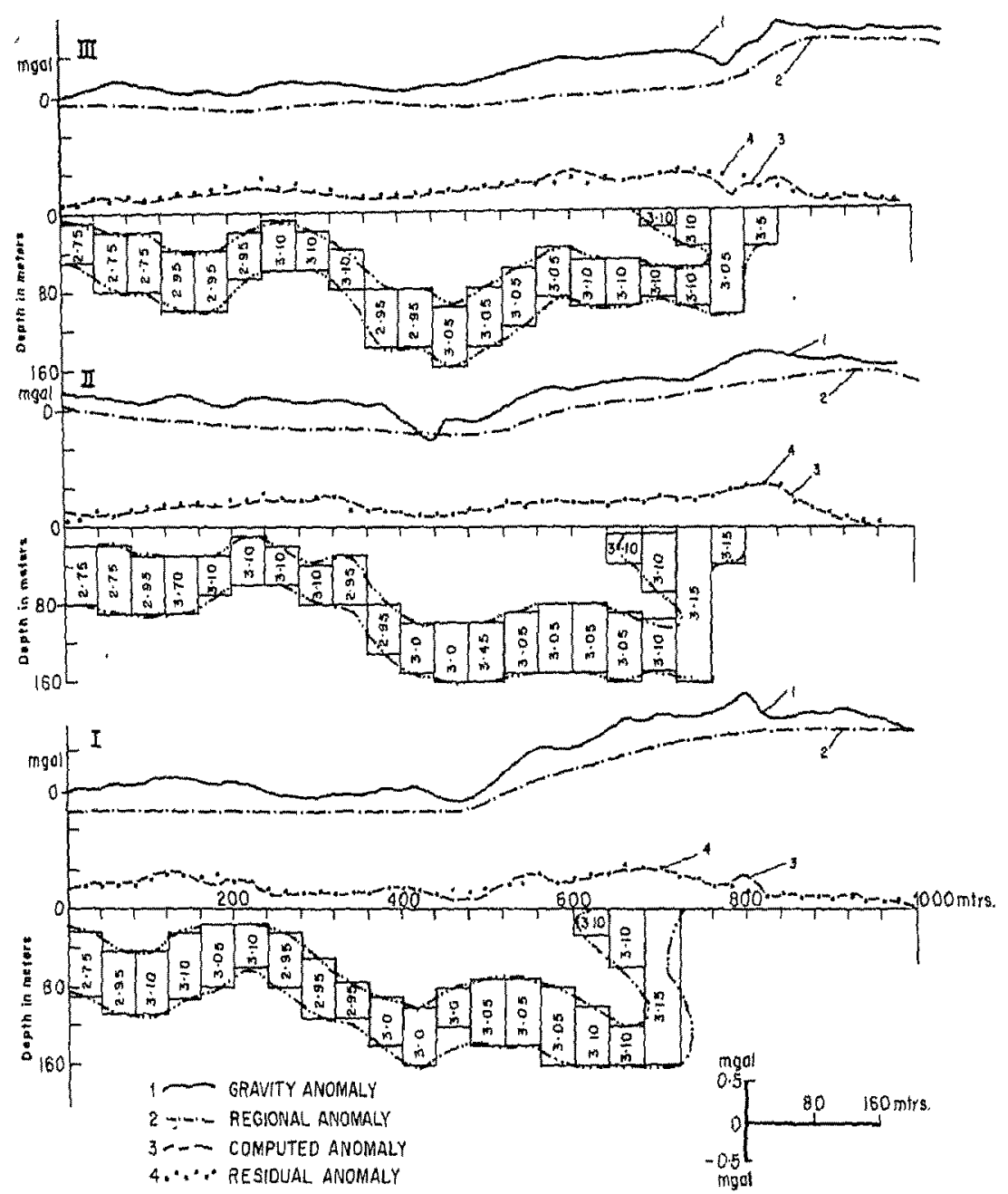

Figure 3. Observed gravity values (relative Bouguer), regional residual and computed residual and inferred gravity model along the traverses (I to III).

dolomitic limestone formation. The contoured sp data is presented in figure 7. The accuracy of gravity values is about $\pm 0.07 \mathrm{mgal}$, while the accuracy of elevations is about $\pm 0.5 \mathrm{~cm}$.

The densities of different types of rocks encountered in the surveys were determined by means of a direct reading densitometer (Bhimasankaram et al 1975). Density determination on more than 200 samples from the surface; and 100 core samples from different geological formations suggest that the average densities are of $2.65 \mathrm{gm} / \mathrm{cm}^{3}$ for carbonaceous shales and green shales; $2.78 \mathrm{gm} / \mathrm{cm}^{3}$ for barren dolomitic limestones and $3.17 \mathrm{gm} / \mathrm{cm}^{3}$ for mineralized dolomitic limestones. Positive density contrasts of $0.13 \mathrm{gm} / \mathrm{cm}^{3}$ between shales and dolomitic limestones (barren) and of $0.39 \mathrm{gm} / \mathrm{cm}^{3}$ between mineralized and barren dolomitic limestones formations exist.

Gravity data of the present detailed work were inverted to get depths to the bottom 

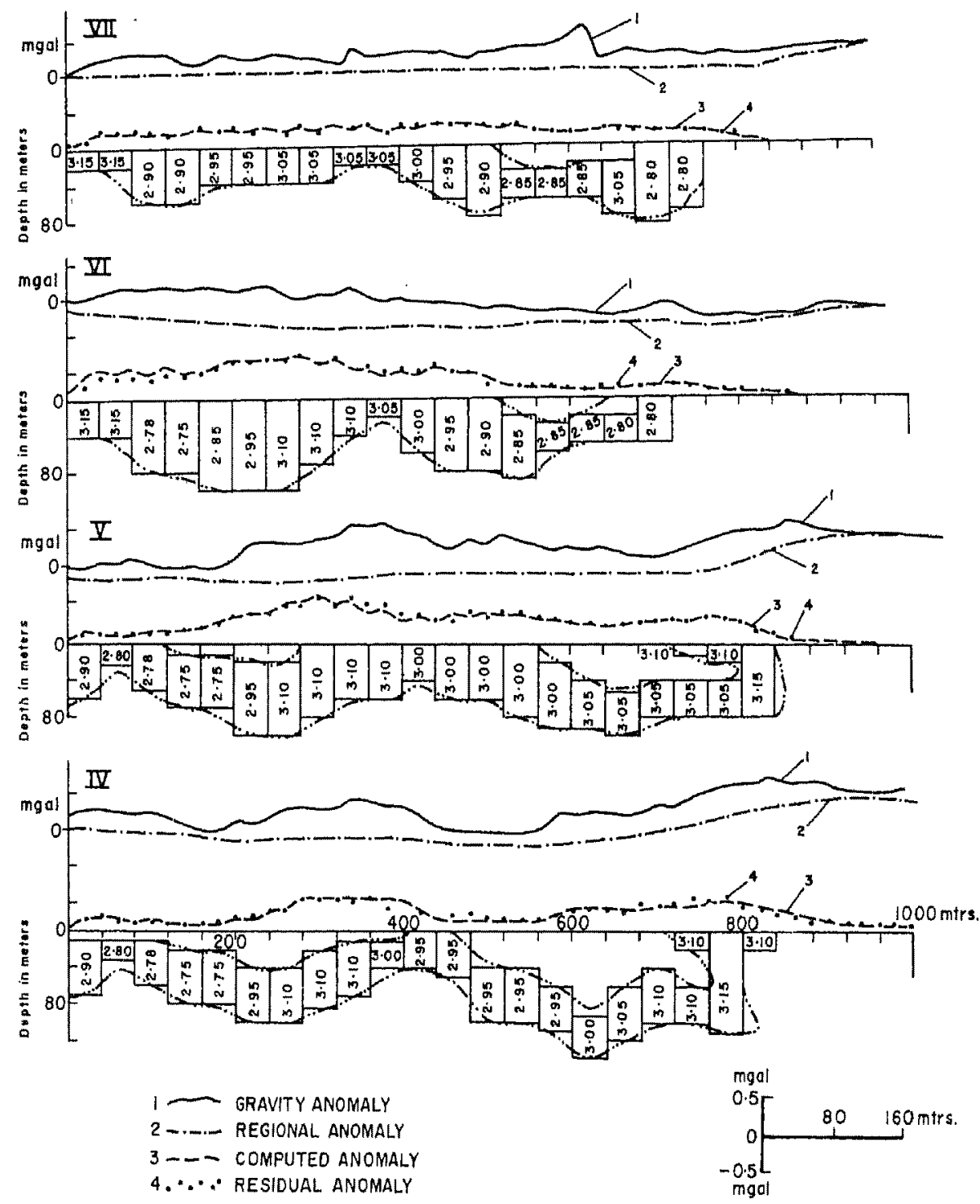

Figure 4. Observed gravity values (relative Bouguer), regional residual and computed residual and inferred gravity model along the traverses (IV to VII).

of the dolomitic limestone horizon. The geology and available borehole data were utilized to fix the regionals along ten detailed gravity traverses. The level of the regionals along all gravity profiles was fitted by assuming uniform conditions. To obtain the residual anomaly along each traverse a graphical smoothening technique was adopted (Rao and Murthy 1978). The resulting regional and residual data are shown in figures 3, 4 and 5 . Residual gravity values thus obtained over all the gravity traverses were further considered for gravity interpretation. Since the variation of 

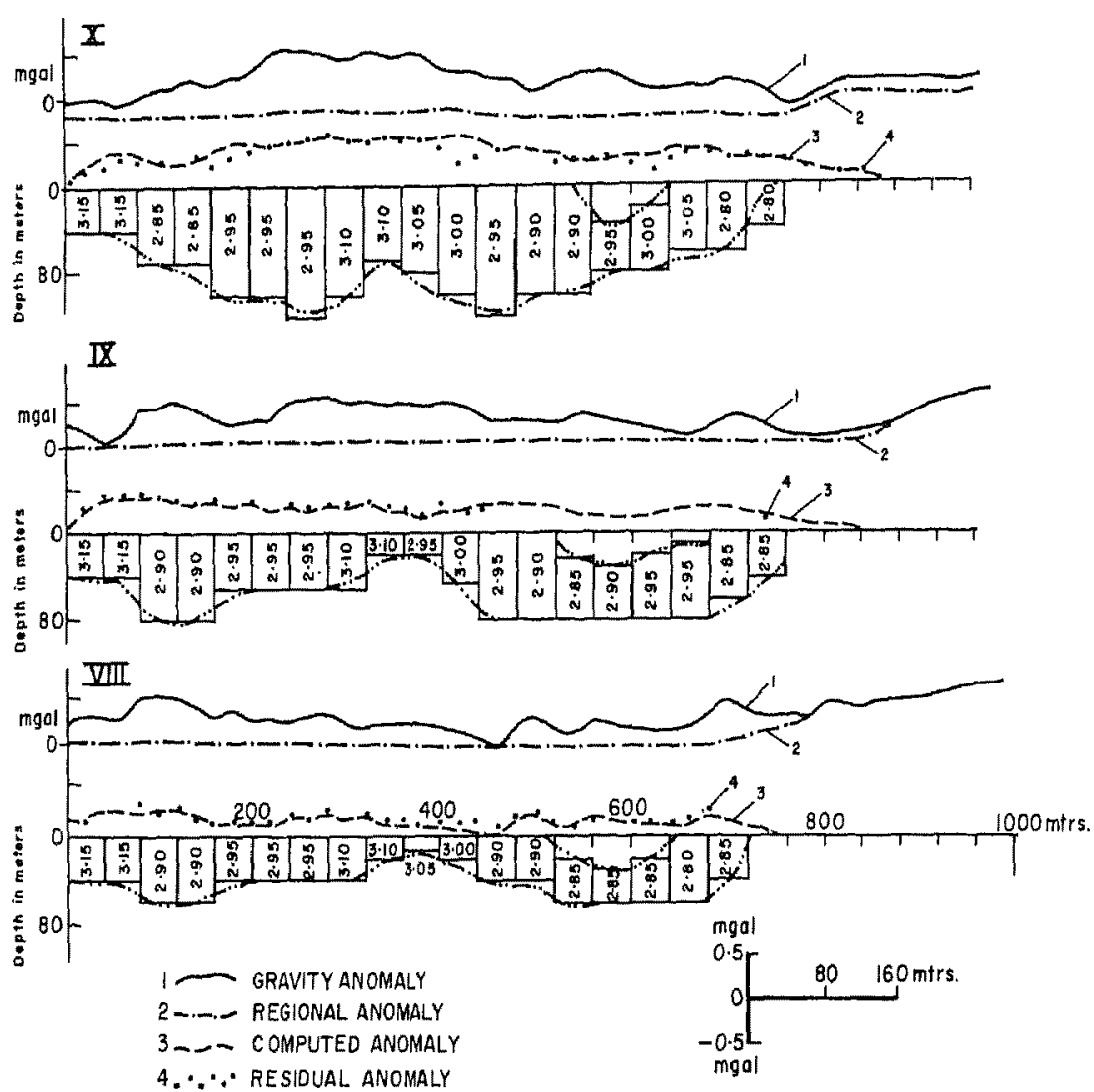

Figure 5. Observed gravity values (relative Bouguer), regional residual and computed residual and inferred gravity model along the traverses (VII to X).

densities along the traverse is large compared to the variation in the thickness of the dolomitic limestones the quantitative analysis is complex. To overcome this hurdle prismatic models with variable densities are used to get the residual Bouguer anomaly. It may be noted that in the first four profiles the dolomitic limestone formations are not exposed except at the eastern end of the profiles, whereas in the remaining profiles the formations are totally exposed. Borehole data which is available along first nine profiles, helped in selecting suitable models, namely vertical prisms and the density contrast of each prism. The gravity values are computed for the model by the formula given below (Heiland 1968):

$$
\begin{aligned}
\Delta g(x)= & \sum_{k=1}^{N} 2 G \sigma_{k}\left[x \cdot \ln \left(\frac{D_{k}^{2}+x^{2}}{d_{k}^{2}+x^{2}}\right)^{1 / 2}-\left(x-b_{k}\right) \cdot \ln \left(\frac{D_{k}^{2}+\left(x-b_{k}\right)^{2}}{d_{k}^{2}+\left(x-b_{k}\right)^{2}}\right)^{1 / 2}\right. \\
& +D_{k}\left(\tan ^{-1} \frac{x}{D_{k}}-\tan ^{-1} \frac{\left(x-b_{k}\right)}{D_{k}}\right) \\
& \left.+d_{k}\left(\tan ^{-1} \frac{x}{d_{k}}-\tan ^{-1} \frac{\left(x-b_{k}\right)}{d_{k}}\right)\right]
\end{aligned}
$$




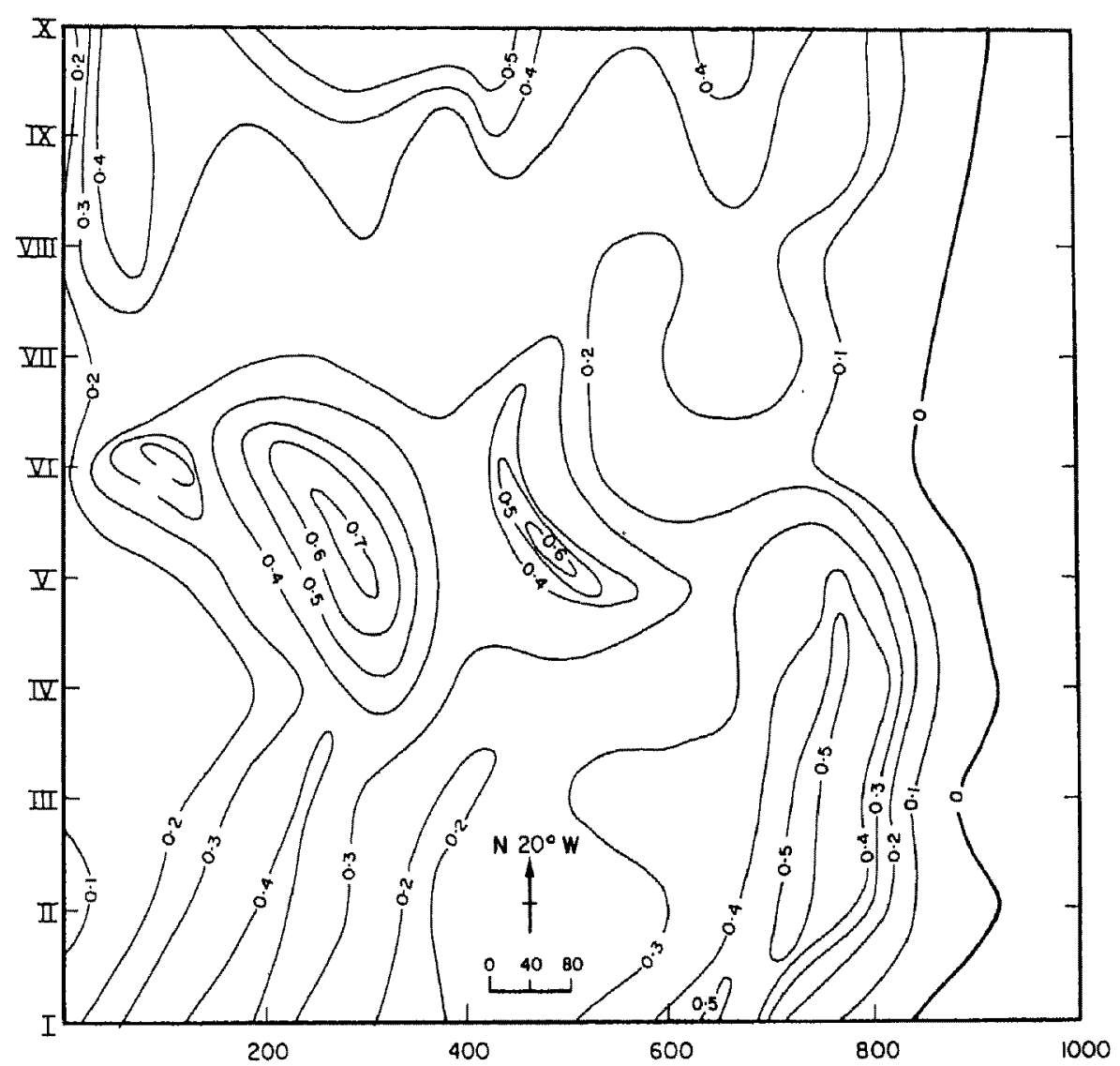

Figure 6. Gravity residual contour map (contour interval $0.1 \mathrm{mgal}$ ).

where $\Delta g$ represents the observed/computed gravity effect, $b$ is half width of the prism, $G$ is the universal gravitational constant $=6.678 \times 10^{-8} \mathrm{cgs}$ units. $\sigma$ is the density contrast in $\mathrm{gm} / \mathrm{cm}^{3}, d$ is the depth to the top of the prism and $D$ is the depth to the bottom of the prism.

The computed effect due to the prism chosen with different parameters was compared with the residual gravity values within the permissible error in the range of $5-10 \%$. This was repeated by varying the parameters of the models to get the close agreement with the residual data (Nettleton 1976). The same procedure was extended for all the profiles.

To delineate the disseminated nature of the base metals, the residual gravity contours were drawn and is shown in figure 6. The sP anomaly contours (figure 7) corroborate in general the gravity residuals.

\section{Identification of tectonic setting using gravity and SP data}

The residual gravity contour map show three main zones namely the eastern, the central and the western zones (from I to VII) where the gravity high can be noticed. On the 


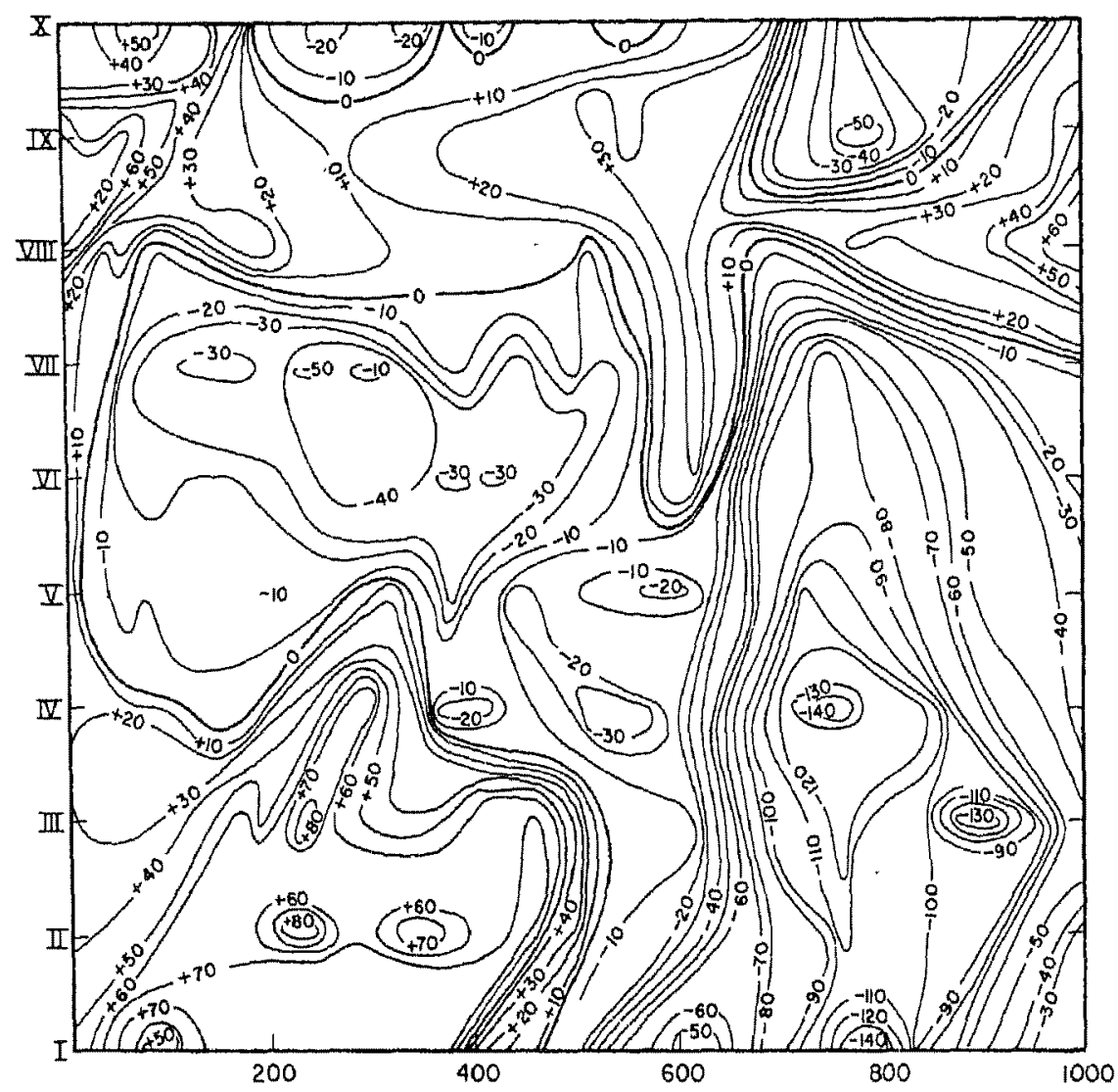

Figure 7. SP contour map (contour interval $10 \mathrm{mv}$ )

eastern side the residual contour seem to indicate that the overturned fold is narrow and fairly straight, which is confirmed from the borehole data. The central region depicts that the overburden effect is relatively high when compared to the eastern zone. The density contrast at the eastern and western ends is relatively higher where mineralization is present. It may be noted that the density of formations overlying and underlying the dolomitic limestone is $2.65 \mathrm{gm} / \mathrm{cm}^{3}$ as was obtained from core samples.

The overturned fold is significant at the eastern end of the profiles I to $V$, whereas the intensity of the folding pattern is diminishing towards the north which can be seen on profiles VI to $X$. The crests and troughs can be seen along the traverses I to IV and along the other traverses the dolomitic limestones are exposed towards the north of the area. From the contour map of the SP data, a low value $(-140 \mathrm{mv})$ can be seen at the eastern end of the first four traverses.

Based on the quantitative estimation of the two dimensional gravity models a model for the entire area of investigation is presented in figure 8 . The surface level which is considered as the base station is situated between traverses V and VI. The folding patterns both along as well as perpendicular to the strike direction can be seen which suggests a doubly plunging nature. 


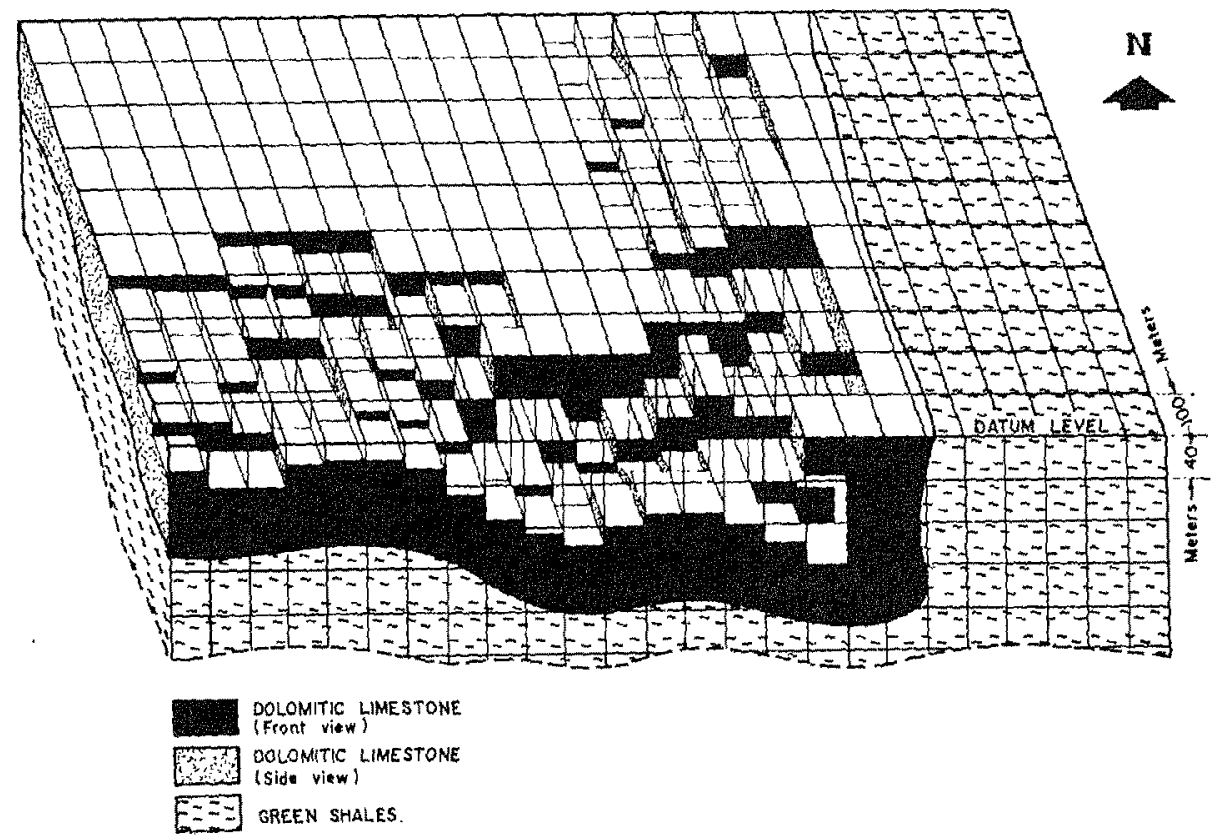

Figure 8. Three-dimensional block model of the Chikativaripalle area (Cuddapah basin), India.

\section{Mineralization}

The lead, zinc and copper deposits at the Chikativaripalle area are of a disseminated type which are localized in narrow bands of folded dolomites occurring within the shales and along steeply dipping overturned zones at the eastern part of the traverses I-V. The increase in density of the blocks in the anticlinal portions of the dolomite band indicates mineral concentration of disseminated nature.

The sp data obtained over a disseminated sulphide ore body in the Chikativaripalle area revealed a negative anomaly of the order of $-70 \mathrm{mv}$ to $-140 \mathrm{mv}$. However, the carbonaceous shales which are present in the synclinal portions show positive sP values of the order of 10 to $30 \mathrm{mv}$. The dolomites which are devoid of any mineralization show values close to zero. From this it may be concluded that negative $S P$ values are observed only over the mineralized zone in this area. It is evident from the contour map of the sp anomaly, that low values of the order of -40 to -140 prevail over the mineralized portions, particularly near the eastern end of the first four traverses.

Also it is revealed from the geochemical analyses that indicated prominent anomalies are due to the presence of sulphides of $\mathrm{Cu}, \mathrm{Zn}$ and $\mathrm{Pb}$ between $720-840 \mathrm{~m}$ depth along the profile with the maximum concentration at $780 \mathrm{~m}$ (figure 9). The analysis of geochemical data shows that the soil over these zones contains 8-64 ppm Cu, 40-640 ppm $\mathrm{Zn}$ and $22-8120 \mathrm{ppm} \mathrm{Pb}$.

The values of all these elements are maximum in the soils over mineralized dolomitic bands. This is the case where bodies are exposed to weathering. In general, $\mathrm{Zn}$ content is low in soils over carbonaceous shales, compared to even barren dolomites. Wherever 


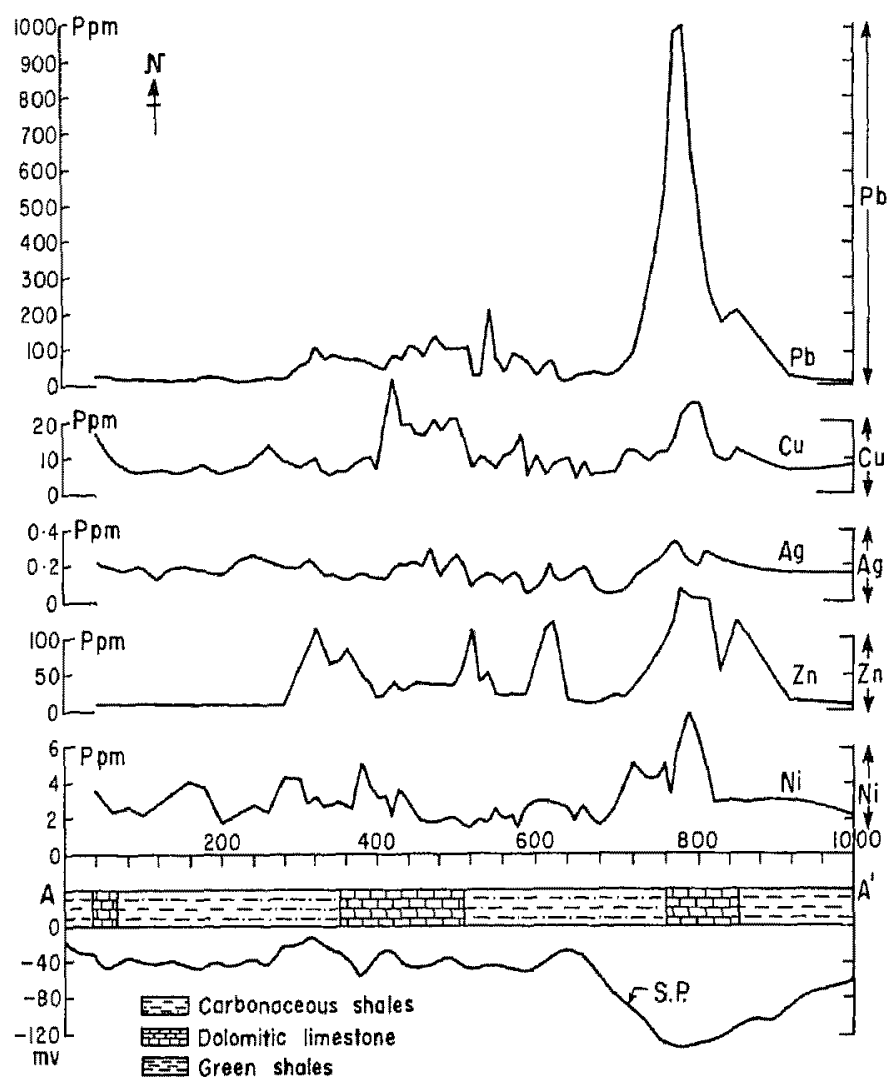

Figure 9. Graph showing variation of $\mathrm{Cu}, \mathrm{Pb}, \mathrm{Zn}, \mathrm{Ni}$ and $\mathrm{Ag}$ elements along traverse $\mathrm{IV}$.

$\mathrm{Zn}$ content is higher in shales than barren dolomites it is mainly due to contamination from the adjacent mineralized zone. Ag content is slightly higher in both mineralized and barren dolomites as compared to shales. The major sulphide minerals of the ore are chalcopyrite, pyrite associated with calcite, sphalerite and galena.

\section{Conclusions}

From the above analysis, residual gravity data closely agree with the SP and are confirmed by geochemical and borehole data. It may be concluded that the gravity method can be effectively used for indirect detection of sulphide deposits.

\section{References}

Balakrishna S, Paul P A and Ramana Rao A V 1970 Bull. Natl. Geophys. Res. Inst. (India) 1 \& 255 Bhimasankaram V L S, Murali Manohar Rao and Satyanarayan Murty B V S 1975 J.Instrum. Soc. India 516 Coulson A L 1933-44 Mem. Geol. Surv. India 64182

Glennie E A 1932 Drof. Paper Survey of India 27 
Heiland C A 1968 Geophysical exploration (New York and London: Hafner)

King W 1872 Mem. Geol. Surv. India 11

Krishnaswamy V S 1981 Explanatory brochure on geological and mineral map of the Cuddapah Basin, p. 1

Krishnaswamy V S 1982 Proc. of the fourth workshop on status, problems and programmes in the Cuddapah Basin, Inst. of Indian Peninsular Geology, Hyderabad, p. 1.

Mathew P M, Sastry I V P, Wahi A K and Dutta Gupta S 1983 Geol. Surv. India, Spec. Publ. 2153

Murthy Y G K, Nagaraja Rao B K and Ramalingaswamy G 1978 Proc, of the workshop on status, problems and programmes in the Cuddapah Basin, Inst, of Indian Peninsular Geology, Hyderabad, p. $4 \mathrm{l}$.

Narayanaswamy 1959 Geol. Soc. India 180

Narayanaswamy 1971 Geol. Soc. India 131

Nettleton L L 1976 Gravity and magnetics in ail prospecting (New York: McGraw-Hill)

Qureshy M N, Krishna Bralmmam N, Aravamadhu P S and Naqui S M 1968 Proc. R. Soc., London A304 449 Ramarao B S R and Murthy I V R 1978 Gravity and magnetic prospecting (India: Arnold Heinemann)

Reddy A G B, Mathew P M and Kailasam L N 1967 Symposium on Upper Mantle project, GRD and NGRI, Hyderabad, 8, p. 286

Tanner J G and Gibb R A 1979 Geol. Surv. of Canada, Econ. Geology Report 31, p. 165 